\title{
Efektivitas Model Pembelajaran Fisika “PRODUKSI" terhadap Peningkatan Aspek-aspek Keterampilan Berkomunikasi Sains
}

\author{
Wirawan Fadly \\ Dosen Jurusan IPA IAIN Ponorogo \\ wira1fadly@gmail.com
}

\begin{abstract}
Abstrak
Penelitian ini bertujuan untuk mengetahui keefektivan penerapan model pembelajaran PRODUKSI dalam meningkatkan aspek-aspek keterampilan berkomunikasi sains. Metode penelitian yang digunakan adalah eksperimen dengan desain one-group pretest-posttet yang direplikasi pada tiga sekolah. Sampel penelitian dipilih secara purposive sampling. Data dikumpulkan dengan menggunakan tes yang kemudian dianalisis berdasarkan karakteristik data. Analisis yang digunakan diantarnya secara deskriptif kuantitatif menggunakan analisa N-Gain dan dan statistik inferensial. Hasil penelitian menunjukkan bahwa model pembelajaran PRODUKSI efektif membantu meningkatkan keterampilan berkomunikasi sains secara signifikan yang meliputi aspek menulis ilmiah, membaca ilmiah, observasi, representasi pengetahuan, dan presentasi informasi siswa pada level sedang.
\end{abstract}

Kata kunci: Model Pembelajaran PRODUKSI, Keterampilan Berkomunikasi Sains.

\begin{abstract}
This research to determine the effectiveness of the application of PRODUKSI learning model to improve aspects of scientific communication skills. The research method used was experiment with one-group pretest-posttet design which replicated at three schools. The sample was chosen by purposive sampling. Data were collected by using tests that were then analyzed based on data characteristics. The analysis used is descriptive quantitative using $N$ Gain analysis and inferential statistics. The results showed that learning model of PRODUKSI efectively and significantly helped to improve the scientific communication skill, including aspects of scientific writing, scientific reading, observation, knowledge representation, and presentation in a moderate level.
\end{abstract}

Keywords: Produksi Learning Model, Scientific Communication Skills 


\section{PENDAHULUAN}

Lemahnya proses pembelajaran merupakan salah satu masalah yang dihadapi dunia pendidikan. Dalam proses pembelajaran, peserta didik kurang didorong untuk mengembangkan kemampuan berkomunikasi. Proses pembelajaran di dalam kelas diarahkan kepada kemampuan untuk menghafal informasi, otak dipaksa untuk mengingat dan menimbun berbagai informasi tanpa diberi ruang untuk mentransfer informasi tersebut kepada masyarakat. Bila individu berinteraksi dan saling mempengaruhi maka terjadilah proses penelaahan, penyampaian, dan penerimaan informasi. ${ }^{1}$

Komunikasi merupakan salah satu komponen utama dalam mendukung pembelajaran abad 21.2 Mengajarkan komunikasi juga dijadikan sebagai salah satu keterampilan yang dikembangkan untuk mendukung kurikulum terbaru saat ini yaitu kurikulum 2013 karena dapat mengembangkan potensi peserta didik untuk mampu berpikir reflektif bagi penyelesaian masalah sosial di masyarakat. Komunikasi juga merupakan bagian penting dalam pembelajaran fisika. Kompetensi inti fisika pada kurikulum 2013 diantaranya adalah dapat merencanakan percobaan, melaksanakan percobaan sesuai kaidah ilmiah, dan mengkomunikasikan pengetahuan ilmiah/hasil percobaan. ${ }^{3}$ Keterampilan untuk dapat mengkomunikasikan pengetahuan ilmiah/hasil percobaan

\footnotetext{
${ }^{1}$ Robert L. Solso, Otto H. Maclin, and M. Kimberly Maclin, "Psikologi Kognitif," Jakarta: Erlangga, 2008.

${ }^{2}$ National Research Council and others, Assessing 21st Century Skills: Summary of a Workshop

(National Academies Press, 2011).

3 "Permendikbud No. 69 Tahun 2013 Tentang Kurikulum Fisika SMA," n.d.
}

disebut juga sebagai keterampilan berkomunikasi sains.

Hasil penelitian pendahuluan yang dilakukan pada salah satu SMA di Bojonegoro, ditemukan bahwa keterampilan berkomunikasi siswa masih belum sesuai dengan harapan. ${ }^{4}$ Kemampuan berkomunikasi efektif pada pembelajaran Fisika di sekolah dalam level sedang dengan nilai rata-rata sekolah 60. Distribusi perolehan nilai sebanyak 10\% memperoleh A (Sangat Baik), 50\% memperoleh B (Baik), 40\% memperoleh $\mathrm{C}$ (Cukup) dan tidak ada siswa yang memperoleh D (Kurang) maupun E (Sangat Kurang). Apabila dilihat dari aspeknya, penyandian (encoding) merupakan aspek yang perlu mendapatkan perhatian dalam mengembangkan kemampuan komunikasi efektif. Temuan pada keterampilan berkomunikasi sains menunjukkan bahwa keterampilan berkomunikasi sains siswa dalam level rendah dengan nilai rata-rata sekolah 50. Distribusi perolehan nilai sebanyak 35\% memperoleh B, 45\% memperoleh C, 20\% memperoleh D, dan tidak ada siswa yang memperoleh $\mathrm{A}$, maupun E. Apabila dilihat pada masingmasing aspeknya, nilai terendah pada kemampuan membaca ilmiah terdapat pada aspek pemahaman kosakata Fisika, menulis ilmiah pada aspek wawasan, presentasi informasi pada aspek penyampaian, representasi pengetahuan hampir pada seluruh aspek, dan observasi ilmiah pada aspek bertanya.

Berdasarkan hasil penelitian pendahuluan tersebut, diketahui bahwa

\footnotetext{
${ }^{4}$ Wirawan Fadly, "Profil Keterampilan Mengomunikasikan Sains Pada Siswa Sekolah Menengah Atas," Jurnal Pendidikan Maja Vidya 2 (2013): 22-30.
} 
pembelajaran fisika yang berlangsung selama ini belum mampu memfasilitasi siswa untuk memiliki kemampuan dalam mengkomunikasikan sains kepada masyarakat, sehingga diperlukan solusi aleternatif berupa model pembelajaran yang ditekankan pada pembelajaran berbasis proyek yang dapat meningkatkan kemampuan berkomunikasi siswa. Adapun model pembelajaran yang dapat dijadikan alternatif solusi tersebut adalah model pembelajaran PRODUKSI. Model pembelajaran PRODUKSI merupakan pengembangan dari pembelajaran berbasis proyek. Model pembelajaran berbasis proyek yang dikembangkan ini lebih diorientasikan pada keterampilan berkomunikasi. Menurut Fadly ${ }^{5}$ model PRODUKSI dapat memfasilitasi kebutuhan siswa dalam kegiatan belajar fisika, karena dapat membantu membuat pengetahuan fisika yang semula abstrak menjadi lebih mudah dicerna melalui aktifitas komunikasi. Model ini terdiri dari enam fase pembelajaran, yang terdiri dari: 1) essential problem, 2) recitation, 3) investigate, 4) design plan project, 5) reflection, 6) discussion, dan 7) project fair.

Model ini menekankan pada aktivitas interaksi dan kolaborasi. Interaksi yang terjadi selama pembelajaran meliputi interaksi social dan lingkungan. Hal ini supaya terbentuk pengonstruksian ide-ide baru dan meningkatkan perkembangan intelektual siswa. Kolaborasi yang dilakukan memberikan motivasi berkelanjutan terhadap tugas-tugas kompleks dengan memperbanyak kesempatan untuk

\footnotetext{
${ }^{5}$ Wirawan Fadly, "Model Pembelajaran Fisika 'PRODUKSI' Untuk Meningkatkan Keterampilan Berkomunikasi Sains" (Disertasi tidak dipublikasikan. Universitas Negeri Surabaya, 2017).
}

melakukan keterampilan berpikir, komunikasi, dan keterampilan sosial. Melalui model pembelajaran PRODUKSI, siswa akan difasilitasi untuk berinteraksi sosial sehingga secara tidak langsung dapat mewujudkan terjadinya transfer pengetahuan, serta memberikan ruang pada siswa untuk berkreasi. Oleh karena itu, akan dilakukan penelitian penerapan model pembelajaran fisika PRODUKSI untuk meningkatkan keterampilan berkomunikasi sains.

\section{KAJIAN TEORI \\ Model Pembelajaran PRODUKSI}

Model pembelajaran PRODUKSI merupakan pengembangan dari pembelajaran berbasis proyek yang dikembangkan oleh Fadly.Model pembelajaran PRODUKSI disebut juga dengan Pembelajaran Berbasis Proyek yang Diorientasikan Menggunakan Keterampilan Berkomunikasi.6 Penyebutan ini sebenarnya juga menunjukkan esensi dari kegiatan pembelajarannya, yang mana berfokus pada kegiatan untuk menghasilkan produk yang dapat dijadikan solusi penyelesaian masalah. Produk yang dihasilkan ini diantaranya dapat berupa catatan lapangan, poster, alat peraga.

$$
\text { Model PRODUKSI dapat }
$$

memfasilitasi kebutuhan siswa dalam belajar fisika karena dapat membantu membuat pengetahuan fisika yang semula abstrak menjadi lebih mudah dicerna melalui aktifitas komunikasi. Menurut Fadly model ini dikembangkan berdasarkan teori konstruktivis-kognitif, konstruktivis-sosial, behavior-kognitif, determinasi diri, dan

\footnotetext{
${ }^{6}$ Ibid.
} 
komunikasi/bahasa. Istilah pada setiap fasenya dikembangkan berdasarkan perspektif teoritis, dimana terdapat beberapa istilah yang diadopsi dari tahapan pembelajaran berbasis proyek, ada yang dimodifikasi sesuai kebutuhan, dan ada yang menggunakan istilah baru. ${ }^{7}$ Urutan pada setiap fasenya disesuaikan dengan tahap intelektual menurut Piaget dan teori pengelolan kelas menurut Glasser. Hal ini dilakukan agar fasenya mudah digunakan dan sesuai dengan perkembangan intelektual siswa dalam belajar. Berdasarkan hasil telaah teoritis dan empiris fase pembelajaran PRODUKSI terdiri dari: (1) menyajikan masalah esensial (essential problem), (2) melakukan resitasi (recitation), (3) melakukan pengamatan dan penyelidikan (investigate), (4) membuat perencanaan proyek (design plan project), (5) melaksanakan proyek dan refleksi kegiatan (reflection), mendiskusikan hasil kegiatan proyek (discussion), dan (7) melakukan pameran hasil proyek (project fair).

Model pembelajaran PRODUKSI memiliki beberapa fitur, salah satunya adalah mengorganisasikan pembelajaran di seputar penyelesaian kasus problematis yang terjadi di lingkungan sekitar siswa. ${ }^{8}$ Masalah disajikan dalam bentuk kasus untuk diselesaikan oleh siswa melalui proses yang kompleks. Proses tersebut dapat berupa kerja proyek yang bertujuan untuk mencari sebanyak mungkin solusi penyelesaian

\footnotetext{
${ }^{7}$ Ibid.

${ }^{8}$ Wirawan Fadly, "Kajian Teoritis Model Productive: Suatu Model Pembelajaran Fisika Berbasis Proyek Yang Dikembangkan Melalui Kegiatan Komunikatif," in Prosiding Seminar Nasional Pendidikan Sains Di Pascasarjana UNS Surakarta (Surakarta, 2014a), 362-70.
}

masalah. Model ini mengharuskan siswa melakukan kegiatan penyelidikan untuk mencari solusi penyelesaian masalah. Kegiatan penyelidikan bergantung pada masalah yang sedang dipelajari. Kegiatan tersebut dapat dilakukan melalui observasi objek, mengumpulkan dan menganalisis informasi, dan membuat kesimpulan.

Fitur lain dari model pembelajaran PRODUKSI adalah mampu memfasilitasi siswa untuk membentuk jaringan belajar. ${ }^{9}$ Jaringan belajar dilakukan agar siswa dapat menggali berbagai informasi untuk membantu proyek yang dilakukan. Jaringan ini dibentuk agar siswa dapat melakukan pemagangan pada ahli, masyarakat, guru, maupun teman sebaya yang lebih mampu untuk mencari sebanyak mungkin informasi yang berguna dalam penyelesaian masalah.

Model pembelajaran PRODUKSI, menuntut siswa untuk aktif melakukan aktivitas komunikasi yang meliputi menulis, membaca, observasi, representasi, presentasi komunikasi verbal dan nonverbal. Model PRODUKSI pada pengelolaan pembelajarannya, memberikan ruang kepada guru dan siswa untuk melakukan komunikasi verbal dan nonverbal. Hal ini bertujuan untuk memfasilitasi terjadinya interaksi di kelas.

Pembelajaran model PRODUKSI dicirikan dengan adanya interaksi dan kolaborasi. Interaksi yang terjadi selama pembelajaran meliputi interaksi sosial, verbal dan lingkungan. Hal ini supaya terbentuk pengonstruksian ide-ide baru dan meningkatkan perkembangan intelektual siswa. Kolaborasi yang

\footnotetext{
${ }^{9}$ Fadly, "Profil Keterampilan Mengomunikasikan Sains Pada Siswa Sekolah Menengah Atas.”
} 
dilakukan memberikan motivasi berkelanjutan terhadap tugas-tugas kompleks dengan memperbanyak kesempatan untuk melakukan keterampilan berpikir, komunikasi, dan keterampilan sosial.

Fitur khas dari model pembelajaran PRODUKSI adalah adanya pameran hasil proyek. Pameran hasil proyek merupakan kegiatan di mana siswa menampilkan, dan membahas pertanyaan penelitian, metodologi, dan temuan dari proyek sains mereka. Pameran hasil karya dapat membantu siswa memahami kualitas hasil karya yang baik dan mengenali kualitaskualitas tersebut dalam produk dan hasil karyanya. Hasil proyek menjelaskan tentang bentuk penyelesaian masalah yang ditemukan siswa kemudian didemonstrasikan kepada orang lain. Hasil proyek yang dipamerkan diantaranya dapat berupa laporan, model fisik, poster, video.

Model pembelajaran PRODUKSI memiliki karakteristik: 1) orientasi pada belajar melalui proses top down, belajar melalui penemuan, kegiatan proyek, belajar otonom, serta pembelajaran yang komunikatif; 2) prinsip adanya pemagangan, scaffolding, kebebasan dalam memilih, serta melatihkan siswa untuk bertanggung jawab atas pilihannya; 3) pembelajaran aktif dan berpusat pada siswa; 4) proses penyampaian informasi yang mengutamakan penggunaan komunikasi verbal dan nonverbal, serta penyampaian informasi melalui verbal dan visual; dan 5) interaksi yang melibatkan interaksi sosial, interaksi verbal, dan interaksi terhadap lingkungan. Model pembelajaran ini dapat diterapkan apabila guru menginginkan kondisi belajar yang lebih diarahkan untuk: 1) menemukan solusi pemecahan masalah, 2) menjadikan siswa belajar secara mandiri, 3) melatih siswa agar dapat berkomunikasi dan berinteraksi dengan baik, 4) membentuk lingkungan belajar aktif di dalam maupun di luar kelas. ${ }^{10}$

\section{Komunikasi Sains}

Komunikasi merupakan bagian penting dari kegiatan ilmiah terutama pada kegiatan ilmiah di bidang sains. Sains disebut sebagai ide baru, konsep, eksperimen atau produk yang dalam satu atau lain cara diperoleh dan diuji menurut metode yang diketahui dan dapat diterima masyarakat pada umumnya. ${ }^{11}$ Treise et al ${ }^{12}$ berpendapat bahwa berkomunikasi tentang sains juga memungkinkan para ilmuwan untuk berbagi wawasan mengenai sifat dunia. Makna pengetahuan ilmiah tidak hanya dibangun oleh kualitas internal atau metode yang dihasilkan, tetapi tergantung pada bagaimana pengetahuan ilmiah bisa dikomunikasikan. ${ }^{13}$ Betapapun luasnya

\footnotetext{
${ }^{10}$ Wirawan Fadly, "Implementasi Model

Pembelajaran Fisika Productive Untuk Meningkatkan Keterampilan Berkomunikasi Sains," in Prosiding Seminar Nasional Fisika Di Jurusan Fisika FMIPA UNESA, 2014b, 09-12.

${ }^{11}$ Elizabeth Stephanie Conradie, "THE ROLE OF KEY ROLE PLAYERS IN SCIENCE COMMUNICATION AT SOUTH AFRICAN HIGHER EDUCATION INSTITUTIONS: AN EXPLORATORY STU DY" (UNIVERSITY OF PRETORIA, 2004),

http://www.repository.up.ac.za/handle/2263/27472.

12 Debbie Treise and Michael F. Weigold, "Advancing Science Communication: A Survey of Science Communicators," Science Communication 23, no. 3 (2002): 310-322.

${ }^{13}$ Lars Holm Nielsen et al., "Credibility of Science Communication" (Tesi, Roskilde University, Natural Science, 2006),
} 
pengetahuan, jika tidak mampu mengkomunikasikan pikiran, pengetahuan, dan wawasan maka tidak akan mampu memberikan transformasi pengetahuannya.

Adapun komunikasi sains memiliki beberapa fungsi yaitu untuk: 1) membantu dalam mengkomunikasikan hasil penelitian, 2) memberikan dukungan dalam kegiatan penelitian, pengajaran, pembuatan keputusan, 3)

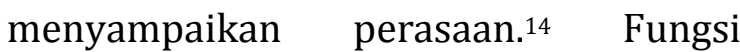
komunikasi sains tersebut penting untuk membangun konsep diri, aktualisasi diri, dan dapat menjalin hubungan dengan orang lain. Komunikasi sains yang efektif antara ilmuan dan masyarakat yang lebih luas dapat menumbuhkan peran aktif masyarakat dalam kegiatan ilmiah, sikap ilmiah dan tambahan khazanah keilmuan. ${ }^{15}$

Komunikasi sains dalam pembelajaran fisika menekankan pada pembelajaran untuk memahami dan mempelajari bahasa ilmiah melalui penerapan prinsip-prinsip pembelajaran (yaitu, menilai pemahaman sebelumnya, menghubungkan fakta untuk kerangka kerja konseptual, pemantauan metakognitif, menetapkan kinerja, dan memberikan umpan balik). ${ }^{16}$ Dalam konsepsi komunikatif, komunikasi sains pada pendidikan fisika adalah transfer

https://pdfs.semanticscholar.org/d5f9/b9e6ffbee0046a 883c2fb046d2df07524483.pdf.

${ }^{14}$ Bo-Christer Björk, "A Model of Scientifitc

Communication of a Global Distributed Information System," Helsinki: Department of Management and Organisation., 2006.

${ }^{15}$ Treise and Weigold, "Advancing Science Communication."

${ }^{16}$ Dale R. Baker et al., "The Communication in Science Inquiry Project (CISIP): A Project to Enhance Scientific Literacy through the Creation of Science Classroom Discourse Communities," 2009, http://digitalcommons.unl.edu/teachlearnfacpub/119/. terus menerus pengetahuan fisika dan metode ke dalam pikiran. Penggunaan komunikasi sains dalam pembelajaran fisika disebut juga sebagai pembelajaran fisika komunikatif, yaitu proses pembelajaran untuk membangun makna fisika dengan melibatkan aktivitas interaksi antar pribadi, penilaian kritis, serta dialog. Melalui pembelajaran fisika komunikatif, siswa akan diberikan ruang untuk melakukan transfer pengetahuan sehingga dapat mewujudkan pengetahuan fisika yang semula abstrak menjadi lebih mudah dicerna. ${ }^{17}$ mengklasifikasikan kemampuan berkomunikasi menjadi: 1) mencari informasi; 2) membaca ilmiah; 3) mendengarkan dan mengamati; 4) menulis ilmiah; 5) merepresentasi informasi; dan 6) mempresentasikan pengetahuan. Berdasarkan hal tersebut, maka komunikasi sains yang efektif antara ilmuan dan masyarakat yang lebih luas dapat menumbuhkan peran aktif masyarakat dalam kegiatan ilmiah, sikap ilmiah dan menambah khazanah keilmuan.

\section{METODE PENELITIAN}

Metode penelitian yang digunakan adalah eksperimen dengan desain onegroup pretest-posttest yang direplikasi pada tiga sekolah. Lokasi penelitian yang digunakan adalah di Bojonegoro, dengan mengambil sampel pada tiga sekolah yang memiliki karakteristik berbeda. Pemilihan sampel penelitian dilakukan secara purposive sampling dengan memperhatikan keberagaman

\footnotetext{
${ }^{17}$ Ornit Spektor-Levy, Bat-Sheva Eylon, and Zahava Scherz, "Teaching Communication Skills in Science: Tracing Teacher Change," Teaching and Teacher Education 24, no. 2 (2008): 462-477.
} 
karakteristik sekolah. Sekolah yang dijadikan sebagai objek penelitian terdiri dari sekolah umum (SMA A), sekolah berbasis asrama (SMA B), dan sekolah kejuruan (SMA C). Agar perlakukan yang diberikan sama, maka dalam penelitian ini menggunakan satu guru model yang telah dilatih menerapkan model pembelajaran PRODUKSI. Data dikumpulkan dengan menggunakan tes yang kemudian dianalisis berdasarkan karakteristik data. Analisis yang digunakan diantarnya secara deskriptif kualitatif, deskriptif kuantitatif melalui analisa skor $N$-Gain. Kriteria skor $\mathrm{N}$-Gain yang digunakan adalah sebagai berikut: "gain tinggi", jika $\mathrm{g} \geq 0,7$; "gain sedang", jika $0,7<\mathrm{g} \leq 0,3 ;$ dan "gain rendah", jika g<0,3.

\section{HASIL DAN PEMBAHASAN}

Keefektifan model PRODUKSI bertujuan untuk mengetahui tingkat keterterapan model ditinjau dari peningkatan aspek-aspek keterampilan berkomunikasi sains siswa yang meliputi kemampuan membaca ilmiah, menulis ilmiah, observasi, representasi pengetahuan, dan presentasi informasi sebelum dan setelah pembelajaran.

$$
\text { Peningkatan aspek-aspek }
$$

keterampilan berkomunikasi sains tersebut kemudian dianalisis menggunakan $N$-gain. Pada aspek pertama keterampilan berkomunikasi sains yaitu membaca ilmiah, dilakukan tes kemampuan membaca pada tiga sekolah. Hasil tes kemampuan membaca ilmiah dapat ditunjukkan pada gambar berikut ini.

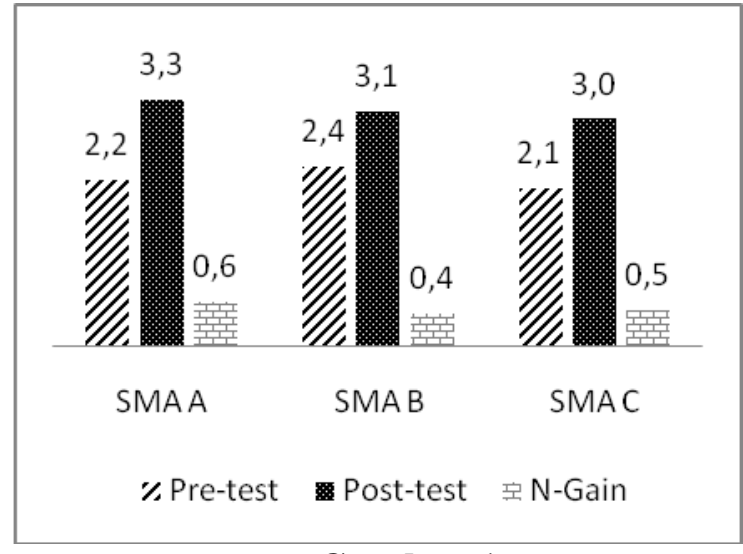

Gambar 1

Hasil Tes Membaca Ilmiah

Berdasarkan Gambar 1, dapat dilihat bahwa ketiga kelas memperoleh kenaikan nilai rata-rata sebelum dan sesudah pembelajaran yang identik pada level sedang, dengan perolehan nilai ratarata peningkatan tertinggi di SMA A. Disamping itu secara keseluruhan model pembelajaran PRODUKSI dapat membantu meningkatkan kemampuan membaca sebagai alat konseptual untuk membantu siswa menganalisis, menafsirkan dan mengomunikasikan ide-ide ilmiah. 18Shanahan menyatakan bahwa siswa yang cakap membaca dalam sains akan mampu belajar konsep, teori, model dan hukum sains lebih mendalam dan menyimpan lebih banyak informasi daripada mereka yang tidak cakap.

Aspek kedua keterampilan berkomunikasi berikutnya adalah kemampuan menulis ilmiah. Hasil tes menulis ilmiah ditunjukkan pada gambar berikut ini.

\footnotetext{
${ }^{18}$ Timothy Shanahan, "Overcoming the Dominance of Communication," Adolescent Literacy Research and Practice, 2004, 59.
} 


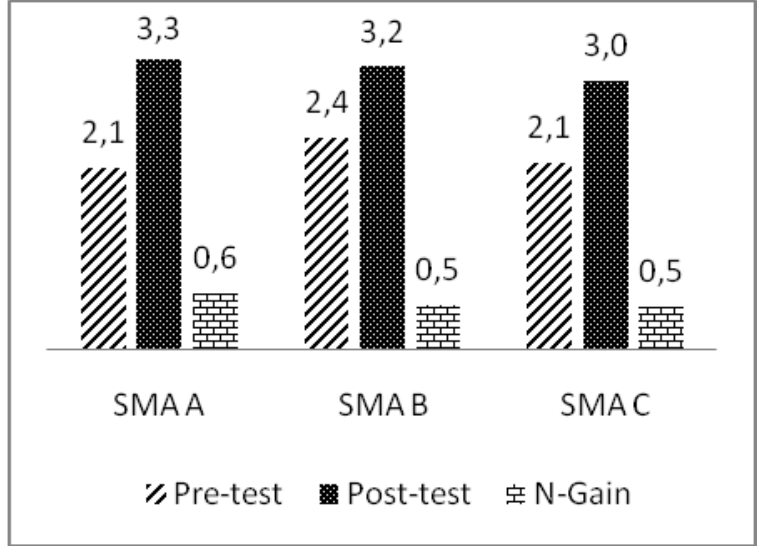

Gambar 2

Hasil Tes Menulis Ilmiah

Gambar 2 menunjukkan bahwa ketiga sekolah memperoleh kenaikan nilai rata-rata kemampuan menulis sebelum dan sesudah pembelajaran pada level sedang, dengan perolehan nilai rata-rata peningkatan tertinggi di SMA A. Hal ini berarti bahwa di sekolah umum mampu memperkuat implementasi model PRODUKSI dalam hal peningkatan aspek kemampuan menulis ilmiah. Secara umum, melalui model PRODUKSI dapat membantu meningkatkan kemampuan menulis ilmiah siswa. Menulis merupakan bagian penting dari pelajaran sains karena dapat membantu seseorang untuk menata pikiran dan menemukan makna dari suatu temuan untuk refleksi bagi diri sendiri dan menyampaikan kepada orang lain. ${ }^{19}$ Dengan memiliki kemampuan menulis ilmiah, maka siswa dapat menguraikan dan membahas suatu permasalahan serta menuangkannya secara sistematis dan terstruktur.

Aspek keterampilan berkomunikasi sains berikutnya adalah observasi. Hasil tes observasi dapat ditunjukkan pada gambar berikut ini.

\footnotetext{
${ }^{19}$ J.W Toppen, Science The Write Way (Terjemahan) (Virginia: National Science Teachers Association., 2011).
}

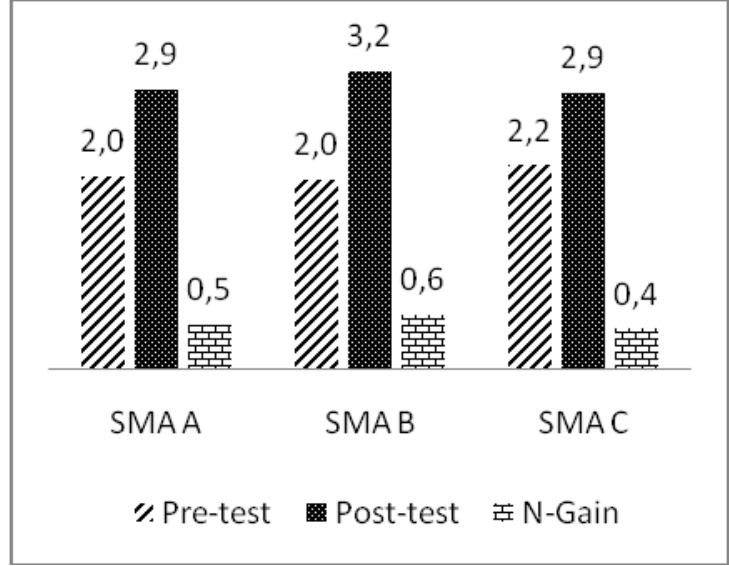

Gambar 3

Hasil Tes Observasi

Observasi merupakan salah satu indikator penting dalam komunikasi sains. Pada gambar 3 menunjukkan bahwa ketiga sekolah memperoleh kenaikan nilai rata-rata sebelum dan sesudah pembelajaran yang identik pada level sedang, dengan perolehan nilai rata-rata peningkatan tertinggi di SMA B. Secara umum, hal ini menunjukkan bahwa melalui model PRODUKSI dapat membantu meningkatkan kemampuan observasi siswa. Bandura ${ }^{20}$ menyatakan bahwa kebanyakan pembelajaran manusia dilakukan dengan mengobservasi perilaku orang lain secara selektif dan menempatkannya dalam ingatan, sehingga sesuatu itu akan mudah dipelajari bila pengamat secara sadar memerhatikan perilaku tertentu dan kemudian meletakkan pengamatan itu kedalam ingatan jangka panjang. Dari sini dapat diketahui bahwa apabila kemampuan observasi dilakukan dengan baik, maka dapat membantu memudahkan memahami sesuatu.

Representasi pengetahuan merupakan salah satu aspek dari

\footnotetext{
${ }^{20}$ R. I. Arend, Learning To Teach (Yogyakarta: Pustaka Pelajar, 2007).
} 
keterampilan berkomunikasi sains. Hasil tes representasi pengetahuan ditunjukkan pada gambar berikut ini.

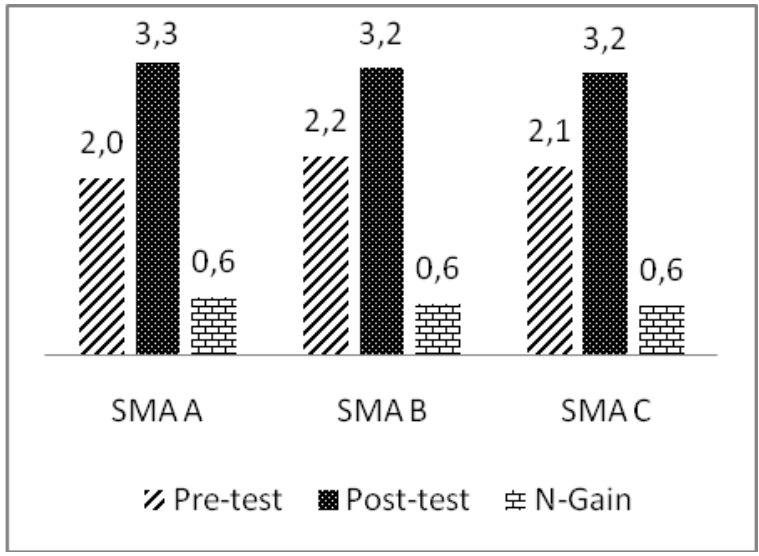

Gambar 4. Nilai rata-rata sebelum dan sesudah

Berdasarkan Gambar 4 menunjukkan bahwa ketiga sekolah memperoleh kenaikan nilai rata-rata sebelum dan sesudah pembelajaran yang identik pada level sedang, dengan perolehan nilai rata-rata peningkatan tertinggi di SMA A. Secara keseluruhan, hal ini menunjukkan bahwa melalui model PRODUKSI dapat membantu meningkatkan kemampuan representasi pengetahuan siswa. Berdasarkan temuan tersebut dapat diketahui bahwa penerapan model pembelajaran efektif meningkatkan aspek-aspek kemampuan representasi informasi. Menurut Luitel ${ }^{21}$ representasi memiliki peranan dalam meningkatkan keefektifan komunikasi, alat mengonstruksi ide-ide, mengatasi hambatan kognitif, serta sebagai alat penghubung antar konsep.

Aspek keterampilan berkomunikasi sains yang terakhir adalah presentasi informasi. Hasil tes presentasi informasi

\footnotetext{
${ }^{21}$ Bal Chandra Luitel, "Representation of Mathematical 1 Earning: A Short Discourse," in 25th Conference Organised by Western Australian Science Education Association, Canning College, 2002.
}

dapat ditunjukkan pada gambar berikut ini.

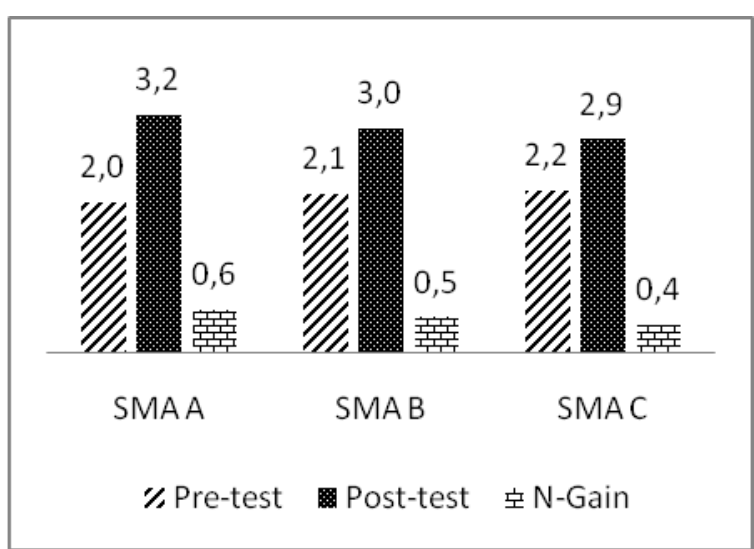

\section{Gambar 5 Hasil Tes Presentasi} Informasi

Hasil penelitian yang ditunjukkan pada Gambar 5 menunjukkan bahwa ketiga sekolah memperoleh kenaikan nilai rata-rata sebelum dan sesudah pembelajaran yang identik pada level sedang, dengan perolehan nilai rata-rata peningkatan tertinggi pada SMA A. Secara keseluruhan, model pembelajaran PRODUKSI dapat membantu meningkatkan kemampuan presentasi pengetahuan. Hal ini sesuai pendapat Woolfolk $^{22}$ yang menyatakan bahwa sebuah ide dengan kata-kata dan mempresentasikannya secara visual dalam bentuk gambar dan ilustrasi dapat membantu meningkatkan pemahaman tentang konsep sains.

Berdasarkan hasil N-gain yang diperoleh bahwa SMA A, SMA B dan SMA C, menunjukkan bahwa rata-rata peningkatan keterampilan berkomunikasi sains siswa sama pada level sedang, tidak ada yang memperoleh tinggi maupun rendah. Berdasarkan hasil perolehan tersebut, maka dapat dikatakan bahwa

\footnotetext{
${ }^{22}$ A Woolfolk, Educational Psychology (Boston: Pearson Education, 2009).
} 
penerapan model pembelajaran PRODUKSI dapat meningkatkan keterampilan berkomunikasi sains siswa pada level sedang. Dari analisis $N$-gain juga menunjukan bahwa dengan menerapkan model pembelajaran PRODUKSI efektif meningkatkan aspekaspek keterampilan berkomunikasi sains siswa. Dengan adanya peningkatan ini, sesuai dengan karakteristik model PRODUKSI menunjukkan bahwa siswa menjadi lebih termotivasi untuk belajar, suasana kelas menjadi lebih interaktif, menekankan interaksi sosial antar siswa, terjadinya transfer pengetahuan serta memberikan ruang pada siswa untuk berkreasi. Hasil peningkatan ini dirasa sangat penting, mengingat komunikasi komunikasi sains merupakan keterampilan utama seorang siswa agar sukses memahami pengetahuan.

Selain menggunakan N-Gain, peningkatan keterampilan berkomunikasi sains dapat diketahui pula dengan menggunakan uji statistik menggunakan uji-t. Namun sebelum melakukan uji-t dilakukan uji normalitas terhadap ke tiga sekolah minitab 16. Berikut Gambar uji normalitas pada masing-masng sekolah.

Tabel 1 Tes Normalitas pada Gain Score Masing-masing Sekolah

\begin{tabular}{llll}
\hline Data & Kelas & $\boldsymbol{\alpha}$ & $\begin{array}{l}\text { P- } \\
\text { Value }\end{array}$ \\
\hline Gain & SMA A & 0,05 & 0.357 \\
Gain & SMA B & 0,05 & 0.179 \\
Gain & SMA C & 0,05 & 0.185 \\
\hline
\end{tabular}

Hasil uji normalitas hasil gain pretest dan post-test keterampilan berkomunikasi di ke tiga sekolah, berdasarkan Tabel 1 dapat diketahui bahwa besar nilai P-Value yang ditunjukkan lebih besar dari $\alpha(0.05)$, dari hasil uji normalitas ini dapat dikatakan bahwa distribusi data skor gain nilai pretest dan post-test keterampilan berkomunikasi di ke tiga sekolah berdistribusi normal.

Uji homogenitas dilakukan selain uji normalitas. Hal ini bertujuan untuk mengetahui sama tidaknya variansivariansi dua buah distribusi. Uji homogenitas terhadap data-data implementasi model PRODUKSI dilakukan dengan menggunakan minitab 16 . Adapun hasilnya dapat dilihat pada tabel berikut.

Tabel 2 Tes Kesamaan Dua Varians untuk Uji Homogenitas

\begin{tabular}{llll}
\hline Data & Kelas & $\boldsymbol{\alpha}$ & Sig. \\
\hline gain & SMA A & & \\
& SMA B & 0,05 & 0.758 \\
& SMA C & & \\
\hline
\end{tabular}

Hasil uji homogenitas pada Tabel 2, dapat diketahui bahwa nilai $P$-Value yang ditunjukkan sebesar 0,758. Hal ini menunjukkan bahwa kesamaan varians di tiga sekolah menghasilkan nilai $P$-Value lebih besar dari $\alpha(0.05)$, sehingga hasil ini menunjukkan bahwa distribusi data keterampilan berkomunikasi di masingmasing sekolah homogen.

Data di ke tiga sekolah menunjukkan bahwa data yang dihasilkan normal dan homogen, sehingga untuk mengetahui keefektifannya dapat dilakukan uji coba statistik melalui uji-t. Pada uji ini masing-masing sekolah dilihat ada tidaknya peningkatan keterampilan berkomunikasi sains. Berdasarkan hasil analisis menggunakan Minitab 16 diperoleh hasil pengolahan data sebagai berikut. 
Tabel 3 Hasil Uji-t Satu Sampel di Tiga Sekolah

\begin{tabular}{llll}
\hline Data & Kelas & $\boldsymbol{\alpha}$ & Sig. \\
\hline Gain & SMA A & 0,05 & 0,000 \\
Gain & SMA B & 0,05 & 0,000 \\
Gain & SMA C & 0,05 & 0,000 \\
\hline
\end{tabular}

Berdasarkan hasil uji statistik tersebut menunjukkan bahwa ke tiga sekolah memiliki $P$-Value 0,000 atau lebih kecil dari nilai $\alpha(0.05)$, sehingga dapat dikatakan terdapat peningkatan nilai keterampilan berkomunikasi sains di seluruh sekolah sampel. Hasil ini menunjukkan bahwa terdapat peningkatan yang signifikan di antara aspek-aspek keterampilan berkomunikasi sains siswa. Dengan adanya peningkatan keterampilan berkomunikasi sains ini menunjukkan bahwa siswa telah terampil dalam memahami dan menyampaikan informasi ilmiah yang bermanfaat untuk masyarakat, lingkungan dan keilmuan. Melalui keterampilan berkomunikasi sains, siswa juga dilatih untuk dapat mempromosikan sains kepada masyarakat umum. Kegiatan ini memberikan keterampilan dan pengalaman kepada masyarakat untuk mengeksplorasi penerapan sains dalam bentuk kegiatan dan eksperimen sains. Hal ini juga sesuai dengan pendapat Treise \& Weigold ${ }^{23}$ yang menyatakan bahwa komunikasi sains yang efektif antara ilmuan dan masyarakat yang lebih luas dapat meningkatkan peran aktif masyarakat dalam kegiatan ilmiah, sikap ilmiah dan tambahan khazanah keilmuan.

\section{KESIMPULAN}

\footnotetext{
${ }^{23}$ Treise and Weigold, "Advancing Science Communication."
}

Model pembelajaran PRODUKSI efektif membantu meningkatkan keterampilan berkomunikasi sains siswa secara signifikan antara keterampilan berkomunikasi sains siswa sebelum dan sesudah kegiatan pembelajaran. Peningkatan juga terjadi pada setiap aspeknya yang meliputi kemampuan menulis ilmiah, membaca ilmiah, observasi, representasi pengetahuan dan presentasi informasi pada level sedang. Konsistensi peningkatan keterampilan berkomunikasi sains hampir merata pada setiap sekolah yang menerapkan model pembelajaran PRODUKSI.

\section{REFERENSI}

Arend, R. I. Learning To Teach. Yogyakarta: Pustaka Pelajar, 2007.

Baker, Dale R., Elizabeth B. Lewis, Senay Purzer, Nievita Bueno Watts, Gita Perkins, Sibel Uysal, Sissy Wong, Rachelle Beard, and Michael Lang. "The Communication in Science Inquiry Project (CISIP): A Project to Enhance Scientific Literacy through the Creation of Science Classroom Discourse Communities," 2009. http://digitalcommons.unl.edu/tea chlearnfacpub/119/.

Björk, Bo-Christer. "A Model of Scientifitc Communication of a Global Distributed Information System." Helsinki: Department of Management and Organisation., 2006.

Conradie, Elizabeth Stephanie. "THE ROLE OF KEY ROLE PLAYERS IN SCIENCE COMMUNICATION AT SOUTH AFRICAN HIGHER EDUCATION INSTITUTIONS: AN EXPLORATORY STU DY." UNIVERSITY OF PRETORIA, 2004. http://www.repository.up.ac.za/ha ndle/2263/27472. 
Council, National Research, and others. Assessing 21st Century Skills: Summary of a Workshop. National Academies Press, 2011.

Fadly, Wirawan. "Implementasi Model Pembelajaran Fisika Productive Untuk Meningkatkan Keterampilan Berkomunikasi Sains." In Prosiding Seminar Nasional Fisika Di Jurusan Fisika FMIPA UNESA, 09-12, 2014b. "Kajian Teoritis Model Productive: Suatu Model Pembelajaran Fisika Berbasis Proyek Yang Dikembangkan Melalui Kegiatan Komunikatif." In Prosiding Seminar Nasional Pendidikan Sains Di Pascasarjana UNS Surakarta, 36270. Surakarta, 2014a.

_-_. "Model Pembelajaran Fisika 'PRODUKSI' Untuk Meningkatkan Keterampilan Berkomunikasi Sains." Disertasi tidak dipublikasikan. Universitas Negeri Surabaya, 2017.

Mengomunikasikan Sains Pada
Siswa Sekolah Menengah Atas."
Jurnal Pendidikan Maja Vidya 2
(2013): 22-30.

Luitel, Bal Chandra. "Representation of Mathematical l Earning: A Short Discourse." In 25th Conference Organised by Western Australian Science Education Association, Canning College, 2002.

Nielsen, Lars Holm, Nanna Torpe Jørgensen, Kim Jantzen, Sanne Bjerg, and D. Sc Birgitte MunchPetersen. "Credibility of Science Communication." Tesi, Roskilde University, Natural Science, 2006. https://pdfs.semanticscholar.org/d 5f9/b9e6ffbee0046a883c2fb046d2 df07524483.pdf.

"Permendikbud No. 69 Tahun 2013 Tentang Kurikulum Fisika SMA," n.d.

Shanahan, Timothy. "Overcoming the Dominance of Communication."
Adolescent Literacy Research and Practice, 2004, 59.

Solso, Robert L., Otto H. Maclin, and M. Kimberly Maclin. "Psikologi Kognitif." Jakarta: Erlangga, 2008.

Spektor-Levy, Ornit, Bat-Sheva Eylon, and Zahava Scherz. "Teaching Communication Skills in Science: Tracing Teacher Change." Teaching and Teacher Education 24, no. 2 (2008): 462-477.

Toppen, J.W. Science The Write Way (Terjemahan). Virginia: National Science Teachers Association., 2011.

Treise, Debbie, and Michael F. Weigold. "Advancing Science Communication: A Survey of Science Communicators." Science Communication 23, no. 3 (2002): 310-322.

Woolfolk, A. Educational Psychology. Boston: Pearson Education, 2009. 